\title{
Pengaruh Semangat Kerja Dan Kecerdasan Emosional Terhadap Kinerja
}

\author{
Daman Yusup \\ Universitas Padjadjaran \\ daman.yusup@unpad.ac.id
}

\begin{abstract}
ABSTRAK
Metode penelitian ini menggunakan pendekatan deskriptif dengan menggunakan kuesioner dari 64 responden, yang dianalisis menggunakan analisis kuantitatif/inferensial, dimana analisis untuk menguji hipotesis atau mengetahui besarnya pengaruh variabel $\mathrm{X} 1$ dan variabel $\mathrm{Y}$ baik secara simultan maupun parsial terhadap variabel Y. Pengolahan data ordinal diubah menjadi skala interval dengan menggunakan MSI. Hasil penelitian menunjukkan bahwa hasil pengujian, walaupun kecil pengaruh langsung antara variabel X1 dengan variabel Y sebesar $28 \%$ sedangkan pengaruh langsung variabel X2 terhadap variabel Y sangat besar pengaruhnya yaitu $44,9 \%$ dan secara simultan variabel X1 dan variabel X2 berpengaruh terhadap variabel Y sebesar 31,3\%.
\end{abstract}

Kata kunci : semangat kerja, kecerdasan emosional, kinerja tenaga kependidikan.

\section{ABSTRACT}

This research uses descriptive approach by using questionnaires from 64 respondents, analyzed using quantitative / inferential analysis, where the analysis to test the hypothesis or know the effect of variable X1 and variable $Y$ either simultaneously or partially to variable Y. Ordinal data processing is converted into scale interval using MSI. The results showed that the test results, although small direct influence between variables X1 with variable $Y$ of $28 \%$ while the direct influence of variable X2 to variable $Y$ is very big influence is $44.9 \%$ and simultaneously variable X1 and variable X2 affect Y variable of $31,3 \%$

Keywords: morale, emotional intelligence, performance of education personnel.

\section{PENDAHULUAN}

\section{Latar Belakang}

Sumber daya manusia merupakan salah satu sumber daya yang paling menentukan sukses tidaknya suatu organisasi, oleh karena itu, organisasi dituntut untuk mengelola sumber daya manusia yang dimiliki dengan baik demi kelangsungan hidup dan kemajuan organsiasi.

Berhasil tidaknya suatu organisasi ditentukan oleh unsur manusia yang melakukan pekerjaan sehingga perlu adanya balas jasa terhadap pegawai sesuai dengan sifat dan keadaannya. Pimpinan organisasi dituntut untuk memperlakukan pegawai dengan baik dan memandang mereka sebagai manusia yang mempunyai kebutuhan baik materi maupun non-materi.

Di sisi lain, pegawai sebagai motor penggerak organisasi dituntut untuk bekerja dengan lebih bersemangat agar mampu menghadapi persaingan, dan dapat mempertahankan keberadaan organisasi. Menurut Hasibuan, organisasi bukan saja mengharapkan pegawai yang mampu, cakap, dan terampil, namun yang lebih penting adalah mereka bersedia bekerja dengan giat dan berkeinginan untuk mencapai hasil kerja yang optimal. Kemampuan, kecakapan, dan keterampilan pegawai tidak ada artinya bagi organisasi jika mereka tidak mau bekerja keras dengan menggunakan kemampuan, kecakapan, dan keterampilan yang dimilikinya.

Pengukuran tingkat prestasi kerja dapat dilakukan dengan terlebih dahulu mengukur semangat kerja. Bila pegawai memiliki semangat yang rendah, maka tingkat prestasi kerjanya pun akan rendah/turun. Namun sebaliknya meningkatnya semangat kerja akan menambah kesetiaan pegawai kepada organisasi untuk tetap mengabdikan dirinya kepada organisasi. Hubungan semangat kerja dengan prestasi kerja pada dasarnya terdapat hubungan yang erat, hal ini sesuai dengan keinginan pegawai dan organisasi, karena dengan semangat kerja pegawai dapat mempengaruhi prestasi kerja.

Setiap manusia ingin berprestasi dalam segala hal, terutama dalam bidang pekerjaan, saat ini keberhasilan dan kesuksesan dalam kerja tidak hanya didukung dari kemampuan intelektual saja, namun juga didukung oleh kemampuan mengelola emosi.

Penelitian Goleman dalam (Wibowo, 2011:9) mengungkapkan bahwa kecerdasan intelektual (IQ) menyumbang sekitar $20 \%$ bagi faktor yang menentukan kesuksesan dalam hidup, sedangkan 
$80 \%$ lainnya dipengaruhi oleh kekuatan lain termasuk kecerdasan emosional. Dalam pernyataan tersebut menunjukkan bahwa di dalam lingkungan kerja, aspek perilaku manusia mengambil peran yang sangat penting.

Kecerdasan emosional yang baik akan membuat seseorang mampu membuat keputusan yang tegas dan tepat walaupun dalam keadaan tertekan. Kecerdasan emosional juga membuat seseorang dapat menunjukkan integritasnya. Orang dengan kecerdasan emosional yang baik mampu berpikir jernih walaupun dalam tekanan, bertindak sesuai etika, berpegang pada prinsip dan memiliki dorongan berprestasi. Kecerdasan emosional berarti menggunakan emosi secara efektif untuk mencapai tujuan dengan tepat, membangun hubungan kerja yang produktif dan meraih keberhasilan di tempat kerja.

\section{TINJAUAN PUSTAKA}

\section{Semangat Kerja}

Nitisemito (dalam Ihsan Nadjamuddin, 2010:01) mendefinisikan, semangat kerja adalah melakukan pekerjaan secara lebih giat sehingga dengan demikian akan dapat diharapkan lebih cepat dan lebih baik. Sementara itu, oleh Knowles (dalam Ihsan Nadjamuddin, 2010:01) semangat kerja diartikan sebagai sikap mental dari individu-individu dan kelompok, semangat kerja tinggi ditandai dengan kesenangan, kegairahan dan mengarah kepada pekerjaan. Semangat kerja muncul dari kepuasan para pekerja di dalam menjalankan pekerjaan dan hubungan-hubungan mereka dengan perusahaan.

Semangat kerja dapat diartikan sebagai semacam pernyataan ringkas dari kekuatan-kekuatan psikologis yang beraneka ragam yang menekan sehubungan dengan pekerjaan mereka. Semangat kerja dapat diartikan juga sebagai suatu iklim atau suasana kerja yang terdapat di dalam suatu organisasi yang menunjukkan rasa kegairahan di dalam melaksanakan pekerjaan dan mendorong mereka untuk bekerja secara lebih baik dan lebih produktif.

Pada umumnya turunnya semangat dan kegairahan kerja karena ketidakpuasan pegawai yang bersangkutan baik secara materi maupun non materi. Untuk dapat meningkatkan semangat dan kegairahan kerja maka dapat dilakukan antara lain dengan jalan : memberikan gaji cukup, memperhatikan kebutuhan rohani, memberikan kesempatan pada mereka untuk maju, sekali perlu menciptakan suasana santai, harga diri perlu mendapatkan perhatian, ditempatkan pada posisi yang tepat, berikan kesempatan kepada mereka untuk maju, perasaan aman untuk menghadapi masa depan, usaha para karyawan memiliki loyalitas, pemberian insentif yang terarah, fasilitas yang menyenangkan dan sebagainya.

Bahkan turunnya/rendahnya semangat dan kegairahan kerja sebenarnya dapat diketahui dengan jalan melihat indikasi-indikasi yang mungkin yang mungkin timbul yaitu antara lain turun/rendahnya produktivits kerja, tingkat absensi yang naik/tinggi dan sebagainya. Sebab turunnya semangat dan kegairahan kerja harus kita ketahui sebab dengan demikian dapat meningkatkan kegairahan kerja, Edduar Hendri, (2010:15).

\section{Kecerdasan Emosional}

Kecerdasan emosional (emotional inteligence) adalah kemampuan untuk mengenali emosi diri, mengelola emosi, memotivasi diri sendiri, mengenali emosi orang lain (empati) dan kemampuan untuk membina hubungan (bekerja sama) dengan orang lain. Goleman (2005:58).

Sementara itu menurut Cooper (2005:387) kecerdasan emosional diartikan sebagai kemampuan merasakan, memahami, dan secara efektif menerapkan daya serta kepekaan emosi sebagai sumber energi, informasi, koneksi, serta dan pengaruh yang manusiawi. Lebih lanjut dikatakan bahwa emosi manusia adalah wilayah dari perasaan lubuk hati, naluri tersembunyi dan sensasi emosi. Apabila dipercayai dan dihormati, kecerdasan emosional menyediakan pemahaman yang lebih mendalam tentang diri sendiri dan orang lain di sekitamya.

Sedangkan menurut pendapat Ary Ginanjar, Agustian (2005 :280) kecerdasan emosional adalah kemampuan merasakan, memahami secara efektif menerapkan daya dan kepekaan emosi sebagai sumber energi, informasi, koneksi dan pengaruh manusia. Emosi adalah bahan bakar yang tidak tergantikan bagi otak agar mampu melakukan penalaran yang tinggi. Emosi menyulut kreativitas, kolaborasi, inisiatif, dan transformasi, dorongan keliru, untuk kemudian menselaraskannya dengan proses kehidupan dengan sentuhan manusiawi, disamping emosi sebagai salah satu kekuatan penggerak.

Menurut hasil penelitian Jacobs dan Chendalam Ary Ginanjar, (386), para peneliti di Hay/Mc Ber London berkesimpulan, Kemampuan kognitif murni adalah terbesar $27 \%$ lebih sering ditemukan pada para-bintang, kinerja dibandingkan pada orangbiasa, sedangkan keunggulan dalam kecakapan emosi mencapai $73 \%$ lebih sering. Dengan kata lain, kecakapan/kecerdasan emosional dua kali lebih berperan dalam menjadikan seseorang berprestasi tinggi, dibandingkan kepandaian murni dan keahlian teknis".

Kecerdasan emosional meliputi kemampuan memantau dan mengendalikan perasaan sendiri dan 
orang lain serta menggunakan perasaan-perasaan itu untuk memandu pikiran dan tindakan dengan cara mengenali emosi diri, mengelola emosi, memotivasi diri sendiri mengenali emosi orang lain dan membina hubungan dengan orang lain. Kinerja karyawan meliputi hasil kerja secara kualitas dan kuantitas yang dicapai karyawan dalam melaksanakan tugasnya sesuai dengan tanggung jawab yang diberikan kepadanya yang meliputi aspek : waktu, produktivitas, biaya, kualitas dan perilaku.

\section{Kinerja}

Rivai \& Sagala (Fonna Mahdani, Hafasnuddin, Muhammad Adam Jurnal Magister Manajemen Unsyiah, 2017:3) memberikan pandangan tentang kinerja pegawai bahwa kinerja (performance) mengacu kepada kadar pencapaian tugas-tugas yang membentuk sebuah pekerjaan karyawan. Kinerja merefleksikan seberapa baik karyawan memenuhi persyaratan sebuah pekerjaan. Sering disalah tafsirkan sebagai upaya (effort), yang mencerminkan energi yang dikeluarkan, kinerja diukur dari segi hasil. Pandangan tersebut sama dengan pandangan Wibowo (2014) bahwa kinerja pegawai dalam organisasi merupakan target hasil baik secara kualitas maupun kuantitas yang diharapkan oleh atasan sesuai dengan standar yang telah ditentukan. Apabila seseorang pegawai dapat menghasilkan sesuai dengan yang diharapkan maka karyawan tersebut dapat dikatakan memiliki kinerja, apabila melebihi yang diharapkan maka kinerja pegawai tersebut dapat dikatakan meningkat atau berprestasi baik. Pandangan Rivai \& Sagala (2010) dan Wibowo (2014) adalah tidak jauh berbeda dengan pengertian kinerja pegawai yang dikemukakan oleh beberapa pakar pakar manajemen dan manajemen sumber daya manusia yang lain, di kinerja pegawai adalah sebagai hasil kerja secara kualitas dan kuantitas yang dapat dicapai oleh seseorang karyawan dalam melaksanakan tugas sesuai dengan tanggung jawab yang diberikan kepadanya.

Pada dasarnya kinerja seorang karyawan merupakan hal yang bersifat individual karena setiap karyawan mempunyai tingkat kemampuan yang berbeda-beda dalam mengerjakan tugas pekerjaannya. Robbins (2012) menyatakan bahwa kinerja dapat diukur dari productivity, turn-over, citizenship dan satisfaction. Kinerja seseorang bergantung pada kombinasi dari kemampuan, usaha dan kesempatan yang diperoleh.

Konstruk kinerja karyawan dalam penelitian ini memiliki enam indikator sebagai dasar pengukurannya, yaitu kuantitas output, kualitas output, ketepatan waktu, kehadiran dalam pekerjaan, efisiensi kerja, dan efektivitas kerja. Hasil analisis deskriptif mengenai kinerja karyawan, Deskripsi konstruk kinerja karyawan yang diukur berdasarkan indikator kuantitas output, kualitas output, ketepatan waktu, kehadiran, efisiensi kerja dan efektivitas kerja, dalam penelitian ini (Mathis dan Jackson; 2011).

\section{METODE PENELITIAN}

Metode penelitian yang digunakan yaitu metode deskriptif analisis dengan pendekatan survey dalam penelitian ini, yang bertujuan untuk mengetahui : Sejauh mana tingkat semangat kerja tenaga kependidikan? Sejauh mana capaian kecerdasan emosional tenaga kependidikan? Bagaimana pengaruh semangat kerja dan kecerdasan emosional terhadap kinerja tenaga kependidikan? dan Upaya apa yang harus dilaksanakakan manajemen untuk meningkatkan kinerja melalui peningkatan semangat kerja dan kecerdasan emosional tenaga kependidikan di Direktorat Sarana Prasarana Universitas Padjadjaran?

\section{Kerangka Pemikiran}

Kerangka pemikiran penelitian ini variabel bebas (X), yaitu Semangat kerja (X1) dan Kecerdasan Emosional (X2), dan Kinerja Tenaga Kependidikan (Y) sebagai variabel terikat.

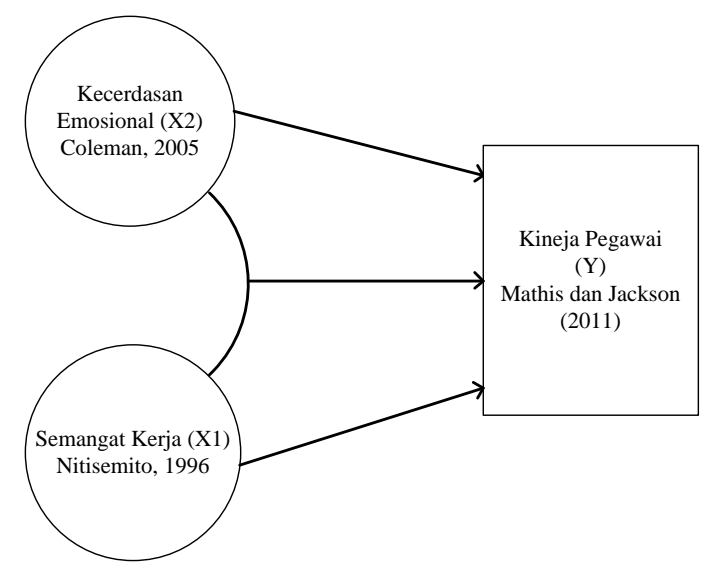

\section{Gambar 1. Skema Kerangka Pemikiran}

Lokasi penelitian dilakukan di Direktorat Sarana Prasarana Universitas Padjadjaran, yang bersumber data tenaga kependidikan yang memiliki 164 orang (data Dit SDM Juli 2017) dengan distribusi sebagai berikut : 
Tabel 1. Distribusi Sampel

\begin{tabular}{cllcc}
\hline No & \multicolumn{1}{c}{ Divisi } & \multicolumn{1}{c}{ Unit } & Populasi & Sampel \\
\hline \hline 1 & Sekre & Perenc, Kepeg & 20 & 4 \\
& & Lingkungan Kampus & 13 & 3 \\
2 & Data Aset & BMN & 2 & 1 \\
3 & Tata Kelola & Humas & 2 & 1 \\
4 & Prasarana & Fasum & 22 & 9 \\
& & Bangunan & 14 & 4 \\
& & Infrastruktur/Jaringan & 17 & 8 \\
& & Stadion Jati & 4 & 3 \\
& & Bale Santika & 3 & 2 \\
5 & \multirow{5}{*}{ Sarana } & UKM \& Mesjid & 9 & 5 \\
& & Workshop & 14 & 7 \\
& & Alat \& Mesin & 4 & 2 \\
& & Pool Dinas & 19 & 11 \\
& & Angkutan Kampus & 16 & 4 \\
\hline & & Toga & 5 & 0 \\
\hline
\end{tabular}

Sumber: Hasil olahan data primer

Data yang dikumpulkan dalam penelitian, yaitu:

1. Data Primer

Dengan melakukan penelitian lapangan, peneliti akan memperoleh data primer, dengan menggunakan kuesioner. Dalam penelitian ini menggunakan kuesioner tertutup untuk pengukuran data, baik menyangkut identitias responden maupun semangat kerja, kecerdasan emosional dan kinerja tenaga kependidikan.

2. Data Sekunder

Data sekunder diperoleh dari Direktorat Sumber Daya Manusia dan Direktorat Tata Kelola dan Komunikasi Publik, sebagai unit layanan terpadu, menginformasikan kegiatan dari Januari sampai dengan November 2017 yang dikelola oleh Direktorat Sarana Prasarana.

Survey menurut Sugiyono (2011:11) adalah metode yang digunakan untuk mendapatkan data dari tempat yang digunakan, kuesioner tertutup yaitu seperangkat daftar pertanyaan tertentu yang alamiah (bukan buatan), tetapi peneliti melakukan perlakuan dalam pengumpulan data, misalnya dengan mengedarkan kuesioner, tes, wawancara struktur dan sebagainya.

\section{HASIL PENELITIAN}

Profil Responden

Tabel 2. Data Responden Berdasarkan Jenis Kelamin

\begin{tabular}{|c|c|c|c|}
\hline No & Jenis Kelamin & $f$ & $\%$ \\
\hline 1 & Laki-laki & 59 & 92,19 \\
\hline 2 & Perempuan & 5 & 7,81 \\
\hline & Jumlah & 64 & \\
\hline
\end{tabular}

Tabel 3. Data Responden Berdasarkan Jenis Pendidikan

\begin{tabular}{cccc}
\hline No & Pendidikan & F & $\%$ \\
\hline 1 & S1 & 13 & 20,31 \\
2 & D3 & 2 & 3,13 \\
3 & SLTA & 41 & 64,06 \\
4 & SL TP & 4 & 6,25 \\
5 & SD & 4 & 6,25 \\
\hline \multicolumn{4}{r}{} \\
\hline
\end{tabular}

Tabel 4. Data Responden Berdasarkan Usia

\begin{tabular}{|c|c|c|c|}
\hline No & Usia & $\mathrm{f}$ & $\%$ \\
\hline 1 & $\varepsilon=30$ tahun & 4 & 6,45 \\
\hline 2 & $31-40$ tahun & 16 & 25,81 \\
\hline 3 & 41-50 tahun & 31 & 50,00 \\
\hline 4 & $>=51$ tahun & 11 & 17,74 \\
\hline & Jumlah & 62 & \\
\hline
\end{tabular}

Tabel 5. Data Responden Berdasarkan Penilaian DP3

\begin{tabular}{cccc}
\hline \multirow{2}{*}{ Kategori } & \multicolumn{2}{c}{ Tahun } & \multirow{2}{*}{ Keterangan } \\
\cline { 2 - 3 } & 2016 & 2017 & $>91$ \\
Sangat Baik & 13 & 51 & $76-90,99$ \\
Baik & 148 & 110 & $61-75$ \\
Cukup & 0 & 0 & $51-60$ \\
Kurang & 0 & 0 & $c=50$ \\
Buruk & 0 & 0 & \\
\hline Rata - rata & 87,86 & 89,06 & \\
\hline
\end{tabular}

Sumber: Sekretariat Dir Sarpras Desember 2017

\section{Analisis Deskriptif Variabel}

Agar lebih mudah dalam menginterpretasikan variabel yang sedang diteliti, dilakukan kategorisasi terhadap tanggapan responden berdasarkan persentase skor responden. Adapun cara mencari nilai persentase maka dibuat interval, dalam penelitian ini penulis menentukan banyak kelas interval sebanyak 5 kategori sesuai banyaknya opsi jawaban pada setiap item pernyataan. Rumus yang digunakan menurut Umi Narimawati (2007:83-85) sebagai berikut:

Tabel 6. Kriterian Pengklasifikasi Persentase Skor Tanggapan Responden

\begin{tabular}{ccc}
\hline No & \% Jumlah Skor & Kriteria \\
\hline 1 & $20.00 \%-36.00 \%$ & Tidak Baik/Sangat Rendah \\
2 & $36.01 \%-52.00 \%$ & Kurang Baik/Rendah \\
3 & $52.01 \%-68.00 \%$ & Cukup \\
4 & $68.01 \%-84.00 \%$ & Baik/Tinggi \\
5 & $84.01 \%-100 \%$ & Sangat Baik/Sangat Tinggi \\
\hline
\end{tabular}

1) Semangat Kerja

Tabel 7. Variabel Semangat Kerja

\begin{tabular}{clcrcc}
\hline No & \multicolumn{1}{c}{ Pernyataan } & Skor Ideal & $\sum$ Skor & $\sum \%$ & kriteria \\
\hline 1 & Harmonis atasan bawahan & 960 & 773,00 & $80,52 \%$ & baik \\
2 & Kepuasan Ekonomi & 960 & 745,00 & $77,60 \%$ & baik \\
3 & Kepuasan dalam bekerja & 960 & 664,50 & $69,22 \%$ & baik \\
4 & Ketenangan Jiwa & 960 & 620,00 & $64,58 \%$ & cukup \\
5 & Iklim bekerja & 960 & 611,00 & $63,65 \%$ & cukup \\
6 & Rasa berguna & 960 & 511,00 & $53,23 \%$ & cukup \\
\hline & & & 3924,50 & $68,13 \%$ & baik \\
\hline
\end{tabular}

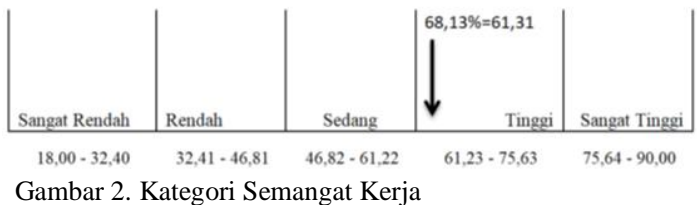


2) Kecerdasan Emosional

Tabel 8. Variabel Kecerdasan Emosional X2

\begin{tabular}{clcccc}
\hline No & \multicolumn{1}{c}{ Pernyataan } & Skor Ideal & $\sum$ Skor & $\sum \%$ & kriteria \\
\hline 1 & Keterampilan Sosial & 3200 & $2.144,00$ & $67,00 \%$ & cukup \\
2 & Pengendalian Diri & 3200 & $2.136,00$ & $66,75 \%$ & cukup \\
3 & Empati & 3200 & $2.120,50$ & $66,27 \%$ & cukup \\
4 & Pengenalan Diri & 3200 & $2.085,50$ & $65,17 \%$ & cukup \\
5 & Motivasi Diri & 3200 & $2.023,50$ & $63,23 \%$ & cukup \\
\hline & & $10.509,50$ & $65,68 \%$ & cukup \\
\hline
\end{tabular}

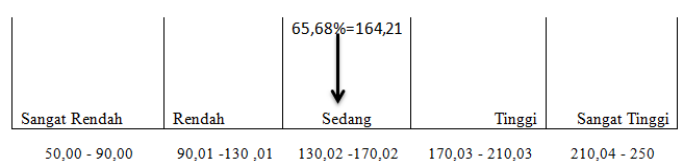

Gambar 3. Katergori Kecerdasan Emosional

3) Kinerja Tenaga Kependidikan

Tabel 9. Variabel Kinerja Tenaga Kependidikan

\begin{tabular}{clcccc}
\hline No & \multicolumn{1}{c}{ Pernyataan } & Skor Ideal & $\sum$ Skor & $\sum \%$ & kriteria \\
\hline 1 & Kuantitas output & 320 & 539,00 & $84,22 \%$ & baik \\
2 & Kualitas output & 320 & 502,00 & $78,44 \%$ & baik \\
3 & Efisiensi dalam menyelesaikan pekerjaan & 320 & 500,00 & $78,13 \%$ & baik \\
4 & Ketepatan waktu & 320 & 492,00 & $76,88 \%$ & baik \\
5 & Kehadiran dlm bekerja & 320 & 474,50 & $74,14 \%$ & baik \\
6 & Efektivitas dlm menyelesaikan pekerjaan & 320 & 471,00 & $73,59 \%$ & baik \\
\hline & & $2.978,50$ & $77,57 \%$ & baik \\
\hline
\end{tabular}

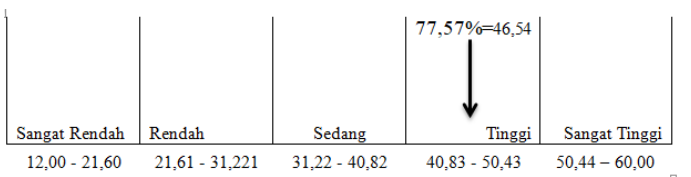

\section{Gambar 4. Katergori Kinerja Tenaga Kependidikan}

Hasil uji kualitas data, diawali dengan uji validitas dan uji reliabilitas sebanyak 64 responden terhadap variabel independen; semangat kerja, kecerdasan emosional dan variabel dependen; kinerja tenaga kependidikan, adalah sebagai berikut :

1. Hasil Uji Validitas

Uji validitas yang digunakan adalah teknik korelasi pearson product moment, pengujian menggunakan program SPSS for windows versi 20. Berdasarkan pengujian validitas dari masingmasing variabel yaitu 80 pertanyaan yang terdiri dari :

a. Semangat Kerja Variabel Independen (X1): 18 pertanyaan

b. Kecerdasan Emosional Variabel Independen (X2) : 50 pertanyaan

c. Kinerja Variabel Dependen (Y): 12 pertanyaan.

Hasil pengolahan menggunakan SPSS dengan titik kritis 0,300 (Sugiyono, 2011:357), dengan demikian sebagian besar instrumen variabel bebas dan variabel terikat valid

\section{Hasil Uji Reliabilitas}

Untuk melihat andal tidaknya suatu alat ukur digunakan pendekatan secara statistika, yaitu melalui koefisien reliabilitas dan apabila koefisien reliabilitasnya lebih besar dari 0,50 maka secara keseluruhan pernyataan tersebut dinyatakan andal (reliabel). Berdasarkan hasil pengolahan menggunakan metode Cronbach'sAlpha diperoleh hasil uji reliabilitas kuesioner masing-masing variabel, nilai r-reliabilitas hitung nilainya lebih besar dari nilai hitung yang sebesar 0,600. Hal ini berarti bahwa seluruh item pertanyaan untuk Variabel X1, X2 dan variabel $\mathrm{Y}$ realibel dan dapat digunakan untuk sebagai alat ukur penilaian.

\section{Uji Asumsi Klasik}

1. Hasil Uji Normalitas

\section{Model Regresi}

Dengan memperhatikan tampilan gambar 5, grafik normal P-Plot di atas, dapat disimpulkan bahwa grafik P-Plot terlihat titik-titik menyebar disekitar garis diagonal, serta arah penyebarannya mengikuti arah garis diagonal. Grafik tersebut menunjukkan bahwa model regresi layak dipakai karena memenuhi asumsi normalitas.

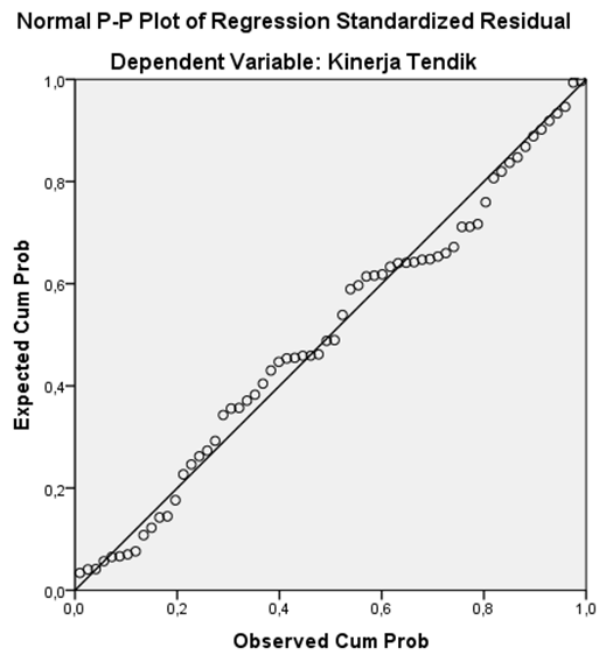

Gambar 5. Grafik Hasil Uji Normalitas 
2. Hasil Uji Heterokedastisitas

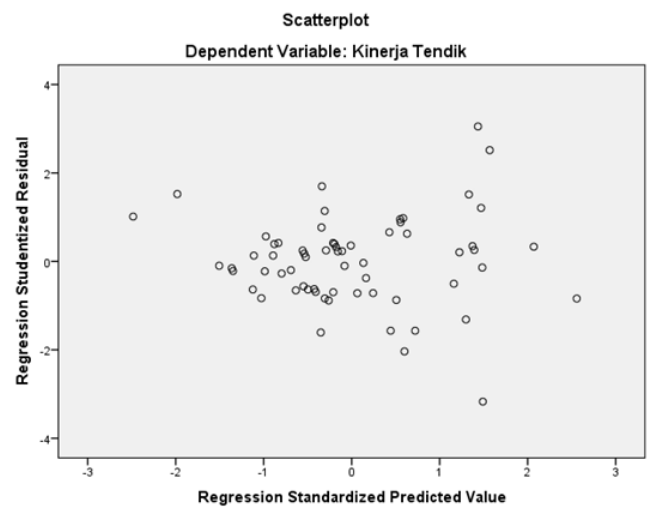

Gambar 6. Uji Heterokedastisitas

Berdasarkan output scatterplots di gambar 6, diketahui bahwa :

a. Titik-titik data penyebar di atas dan di bawah atau disekitar angka 0.

b. Titik-titik tidak mengumpul hanya di atas atau di bawah saja.

c. Penyebaran titik-titik data tiak membentuk pola bergelombang melebar kemudian menyempit dan melebar kembali.

d. Penyebaran titik-titik data tidak berpola

Dengan demikian dapat kita disimpulkan bahwa tidak terjadi masalah heteroskedastisitas, hingga model regresi yang baik dan ideal dapat terpenuhi.

\section{Hasil Uji Autokorelasi}

Tabel 10 Hasil Uji Autokorelasi

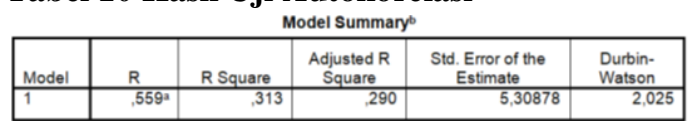

a. Predictors: (constant), kecerdasan emosional, semangat kerja

b. Dependent variabel: Kierja tendik

Berdasarkan tabel 10 diketahui DW 2,025, selanjut nilai ini akan kita bandingkan dengan nilai tabel signifikansi 5\%, jumlah sampel 64 dan jumlah variabel independen $2(\mathrm{~K}=2)=2 ; 64$ (tabel Durbin Watson), maka diperoleh nilai dU 1,652 .

Nilai DW 2,025 lebih besar dari batas atas dU yakni 1,652 dan kurang dari (4-dU); 4 - 1,652= 2,348 sehingga dapat disimpulkan bahwa tidak terjadi autokorelasi.
4. Hasil Uji Multikolinearitas

Tabel 11. Hasil Uji Multikolinearitas Setiap Variabel

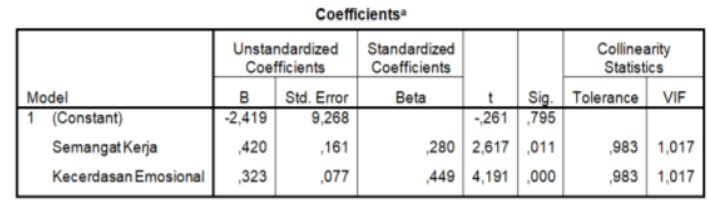

Nilai Tolerence variabel Semangat Kerja (X1) dan Kecerdasan Emosional (X2) yakni 0,983 lebih besar dari 0,10 . Sementara itu nilai VIF variabel Semangat Kerja (X1) dan Kecerdasan Emosional (X2) yakni 1,017 lebih kecil dari 10,00. Sehingga dapat disimpulkan tidak terjadi gejala multikolinearitas antar variabel independent pada model regresi.

\section{Hasil Uji Pengaruh}

1) Hasil Analisis Regresi Linier Berganda

Output regresi pada tabel 11 bagian Coefficients dapat diketahui bahwa nilai signifikansi dari kedua variabel yaitu X1 $=0.000$ dan X2 $=0,000$ lebih kecil dari 0,05. Hasil ini memberikan kesimpulan bahwa variabel X1 dan $X 2$ berpengaruh signifikan terhadap $Y$.

Besaran nilai R2 atau R Square pada tabel 10 Model Summary adalah sebesar 0,313, hal ini menunjukkan bahwa kontribusi atau sumbangan pengaruh X1 dan X2 terhadap $Y$ adalah 31,3\% sementara sisanya $68,7 \%$ merupakan kontribusi dari variabel-variabel lain yang tidak dimasukkan dalam penelitian.

Berdasarkan tabel 11 pula didapat persamaan regresi berganda, yaitu:

$$
\mathrm{Y}=-2,419+0,280 \mathrm{X} 1+0,449+e
$$

2) Hasil Uji-t

Bertujuan untuk mengetahui apakah variabel bebas (X) secara parsial (sendiri) berpengaruh signifikan terhadap variabel terikat (Y) dengan $\alpha$ $=0,05$.

Sesuai tabel 11 dapat dijelaskan. Nilai $\mathrm{t}$ hitung variabel Semangat Kerja $(\mathrm{X} 1)=2,617$, dan $\mathrm{t}$ tabel $=1,999$ (tabel distribusi-t 0,025;61) dimana $t$ hitung $>t$ tabel $(2,617>1,999)$ dan sig. $0,011<0,05$ menandakan signifikan, dengan demikian Semangat Kerja (variabel bebas) berpengaruh terhadap Kinerja Tenaga Kependidikan (variabel terikat). 
Begitupun dengan Kecerdasan Emosional $(\mathrm{X} 2)=4,191$, dan $\mathrm{t}$ tabel $=1,999$ (dist- $\mathrm{t}$ $0,025 ; 61)$ dimana $\mathrm{t}$ hitung $>\mathrm{t}$ tabel $(4,191>$ 1,999) dan sig. $0,000<0,05$ menandakan signifikan, dengan demikian Kecerdasan Emosional (variabel bebas) berpengaruh terhadap Kinerja Tenaga Kependidikan (variabel terikat).

\section{3) Hasil Uji-F}

Bertujuan untuk mengetahui pengaruh dari 2 (dua) variabel bebas secara simultan (bersama) terhadap variabel terikat.

Tabel 12. Hasil Uji F

\begin{tabular}{|l|r|r|r|r|r|}
\hline \multicolumn{1}{|c|}{ ANOVA $^{\text {Sodel }}$} & \multicolumn{1}{c|}{$\begin{array}{l}\text { Sum of } \\
\text { Squares }\end{array}$} & \multicolumn{1}{c|}{ df } & Mean Square & F & Sig. \\
\hline 1 Regression & 781,712 & 2 & 390,856 & 13,868 &, $000^{b}$ \\
Residual & 1719,169 & 61 & 28,183 & & \\
$\quad$ Total & 2500,880 & 63 & & & \\
\hline
\end{tabular}

a. Dependent variabel: Kierja tendik

b. Predictors: (constant), kecerdasan emosional, semangat kerja

Nilai $F$ sebesar 3,15 (tabel distribusi-F probabilitas $=0,05 ; 2 ; 61$ ). Karena nilai $\mathrm{F}$ hitung $13,868>\mathrm{F}$ tabel 3,15, maka dapat ditarik kesimpulan bahwa variabel bebas X1 dan X2 (secara simultan) berpengaruh terhadap variabel terikat (Y).

Dari tabel 12 di atas, diketahui nilai signifikansi sebesar 0,000. Karena nilai signifikansi $0,000<0,05$ sesuai dengan dasar pengambilan keputusan dalam Uji-F, maka disimpulkan $\mathrm{H}_{0}$ ditolak dan $\mathrm{H}_{1}$ diterima, yang artinya "Semangat Kerja (X1) dan Kecerdasan Emosional (X2) secara simultan berpengaruh terhadap Kinerja (Y).

4) Hasil Uji Koefisien Determinasi (R2)

Berdasarkan tabel 10 didapat hasil nilai koefisien determinasi (R Square) sebesar 0,313= $31,3 \%$. Angka tersebut mengandung arti bahwa Semangat Kerja dan Kecerdasan Emosional berpengaruh terhadap Kinerja sebesar $31,3 \%$. Sedangkan sisanya $68,7 \%$ dipengaruhi oleh variabel lain diluar model yang tidak dijelaskan dalam penelitian ini

\section{HASIL DAN PEMBAHASAN}

Adapun pembahasan penelitian ini adalah:

1. Pengaruh Semangat Kerja terhadap Kinerja Tenaga Kependidikan

Berdasarkan hasil penelitian yang telah diuraikan dengan menggunakan SPSS versi 20, diketahui bahwa Semangat Kerja (X1) berpengaruh signifikan terhadap Kinerja Tenaga Kependidikan. Simpulan tersebut didasarkan pada hasil uji statistik t yang menunjukkan hasil t hitung Semangat Kerja (X1) sebesar 2,617 lebih besar dari t tabel 1,999, nilai signifikan hasil uji t statistik Semangat Kerja 0,011 dibawah $\alpha$ (alpha) 0,011 < 0,05 maka dapat disimpulkan Semangat Kerja berpengaruh signifikan dan positif terhadap Kinerja Tenaga Kependidikan (Y) berarti Semangat Kerja mampu mendorong peningkatan kinerja tenaga kependidikan.

Hasil penelitian ini sejalan dengan penelitian yang dilakukan oleh Edduar Hendri Pengaruh Semangat Kerja terhadap Kinerja Pegawai Fakultas Ekonomi Universitas PGRI Palembang, Jurnal Media Wahana Ekonomika Volume 7 No.2 Juli 2010 pp 13-25 yang hasil penelitiannya semangat kerja berpengaruh positif dan signifikan terhadap kinerja pegawai.

Hasil penelitian ini sejalan dengan penelitian yang dilakukan oleh Karsini Pengaruh Semangat Kerja dan Disiplin Kerja terhadap Kepuasan Kerja yangberdampak pada Kinerja Pegawai Dinas Pengelolaan Keuangan dan Aset Daerah (DPKAD) Kota Semarang, Journal of Management Volume 2 No.2 Maret 2016 yang hasil penelitiannya semangat kerja berpengaruh positif dan signifikan terhadap kinerja pegawai.

2. Pengaruh Kecerdasan Emosional terhadap Kinerja Tenaga Kependidikan

Berdasarkan hasil penelitian yang telah diuraikan dengan menggunakan SPSS versi 20, diketahui bahwa Kecerdasan Emosional (X2) berpengaruh signifikan terhadap Kinerja Tenaga Kependidikan. Simpulan tersebut didasarkan pada hasil uji statistik t yang menunjukkan hasil $\mathrm{t}$ hitung Kecerdasan Emosional (X2) sebesar 4,191 lebih besar dari $\mathrm{t}$ tabel 1,999, nilai signifikan hasil uji $\mathrm{t}$ statistik Kecerdasan Emosional 0,000 dibawah $\alpha$ (alpha) 0,000 $<0,05$ maka dapat disimpulkan Kecerdasan Emosional berpengaruh signifikan dan positif terhadap Kinerja Tenaga Kependidikan (Y) berarti Kecerdasan Emosional mampu mendorong peningkatan kinerja tenaga kependidikan.

Hasil penelitian ini sejalan dengan penelitian yang dilakukan oleh Putu Agus Erick Sastra Wirawan Pengaruh Kecerdasan Emosional terhadap Kepuasan dan Kinerja Karyawan PT. JASA RAHARJA (persero) CABANG BALI, Jurnal Ekonomi \& Bisnis JAGADITHA Volume 3 No.1 Maret 2017 pp 12-26 yang hasil penelitiannya kecerdasan emosional berpengaruh positif dan signifikan terhadap kinerja karyawan

3. Pengaruh Semangat Kerja dan Kecerdasan Emosional secara simultan terhadap Kinerja Tenaga Kependidikan

Berdasarkan hasil penelitian yang telah diuraikan dengan menggunakan SPSS versi 20, diketahui bahwa Semangat Kerja (X1) dan Kecerdasan Emosional (X2) secara simultan berpengaruh signifikan terhadap Kinerja Tenaga Kependidikan. Kesimpulan tersebut didasarkan 
hasil uji statistik $\mathrm{F}$ yang menunjukkan hasil $\mathrm{F}$ hitung Semangat Kerja (X1) dan Kecerdasan Emosional (X1) sebesar 13,868 lebih besar pada nilai $\mathrm{F}$ tabel 3,15.

Nilai signifikan hasil uji F Semangat Kerja (X1) dan Kecerdasan Emosional (X2) sebesar 0,000 dibawah $\alpha$ (alpha) yang telah ditentukan yaitu 0,05 maka dapat disimpulkan Semangat Kerja (X1) dan Kecerdasan Emosional (X2) berpengaruh signifikan dan positif terhadap Kinerja Tenaga Kependidikan.

\section{KESIMPULAN DAN SARAN}

\section{Kesimpulan}

Berdasarkan hasil penelitian dan pembahasan yang telah diuraikan sebelumnya disertai dengan teori-teori yang mendukung mengenai pengaruh semangat kerja dan kecerdasan emosional terhadap kinerja tenaga kependidikan, maka penulis mengambil beberapa kesimpulan sebagai berikut:

1. Terdapat pengaruh yang signifikan secara simultan dari semangat kerja dan kecerdasan emosional terhadap kinerja tenaga kependidikan Direktorat Sarana Prasarana.

2. Hubungan secara parsial antara semangat kerja dan kecerdasan emosional terhadap kinerja tenaga kependidikan Direktorat Sarana Prasarana adalah sebagai berikut :

a. Semangat kerja berpengaruh secara signifikan positif terhadap kinerja tenaga kependidikan yang artinya semakin tinggi semangat kerja seorang tenaga kependidikan maka akan menghasilkan kinerja tenaga kependidikan yang meningkat.

b. Kecerdasan emosional berpengaruh secara signifikan positif terhadap kinerja tenaga kependidikan yang artinya semakin tinggi kecerdasan emosional seorang tenaga kependidikan maka akan menghasilkan kinerja tenaga kependidikan yang meningkat pula.

\section{Saran}

Berdasarkan hasil penelitian sebelumnya serta pembahasan yang disertai dengan teori yang mendukung, penulis menyarankan beberapa hal sebagai berikut :

1. Tenaga kependidikan sebaiknya terus meningkatkan kemampuannya di dalam tupoksi. tenaga kependidikan juga diharapkan mematuhi standard dan kode etik sehingga akan meningkatkan kinerja dari tenaga kependidikan itu sendiri yang berujung pada meningkatnya kepercayaan civitas akademik dan customer lainnya, dengan mempelajari melaksanakan aturan yang diberlakukan oleh Universitas.

2. Tenaga kependidikan sebaiknya terus memperkaya pengalaman dalam melakukan tugas, sehingga wawasan dan keterampilan akan terus bertambah, ikut serta pelatihan-pelatihan yang kompeten dengan tupoksi.

3. Tenaga kependidikan sebaiknya menambah kepercayaan dirinya dengan menambah pengetahuan dengan cara mengikuti pelatihan baik kepribadian maupun teknis agar dapat mencapai hasil pekerjaan yang diinginkan.

4. Tenaga kependidikan sebaiknya tidak bergantung pada dorongan dari luar seperti nasib dan koneksi untuk mencapai apa yang diinginkan melainkan percaya pada kemampuan pada diri sendiri, dengan menambah dan mencari sumbersumber informasi.

Bagi penelitian selanjutnya, penelitian ini hanya sebatas ruang lingkup Direktorat Sarana Prasarana Universitas Padjadjaran, oleh karena itu perlu diteliti lebih lanjut pada organisasi yang lebih luas di luar Direktorat Sarana Prasarana Universitas Padjadjaran, agar dapat mengaktualisasi penelitian secara luas

\section{DAFTAR PUSTAKA}

Ary G. dan Agustian (2006), Rahasia Sukses Membangun Kecerdasan Emosi dan Spiritual : ESQ Emotional Spiritual Quotient, Penerbit Arga, Jakarta,.

Cooper, Robert K. (2002), Executive EQ: Kecerdasan Emosional dalam Kepemimpinan dan Organisasi, PT. Gramedia Pustaka Utama, Jakarta.

Edduar Hendri, (2010). Pengaruh Semangat Kerja terhadap Kinerja Pegawai Fakultas Ekonomi Universitas PGRI Palembang, Jurnal Media Wahana Ekonomika, Vol. 7, No.2 : p13 - 25, Juli 2010

Fonna Mahdani, Hafasnuddin dan Muhammad Adam (2017), Pengaruh Motivasi, Kecerdasan Emosional dan Keadilan Organisasi Terhadap Kepuasan Kerja Serta Implikasinya Pada Kinerja Karyawan, Jurnal Magister Manajemen Volume 1, No. 1, ISSN 2302-0199 pp. 1- 15 September 2017

Goleman, Daniel (2005). Working With Emotional Intelligence. Terjemahan Alex Tri Kantjono W. Jakarta: Gramedia Pustaka Utama. Ihsan Nadjamuddin (2010), Pengaruh Semangat Kerja dan Kecerdasan Emosional terhadap Kinerja Karyawan, Jurnal IImiah Penelitian Manajernen, MANAJERIAL Vol. 8 NO.2 September 2010.

Karsini, Patricia Dhiana Paramita danMaria Magdalena Minarsih (2016), Pengaruh Semangat Kerja dan Disiplin Kerja terhadap Kepuasan Kerja yang berdampak pada Kinerja Pegawai Dinas Pengelolaan Keuangan dan Aset Daerah (Dpkad) Kota Semarang, Journal Of Management, Volume 2 No. 2 Maret 2016. 
Knowles, William H. (1991), Personell Management, American Book Co, New York.

Mathis, Robert L. dan Jackson, John H (2011). Human Resource Management. Thirteen Edition. USA : South Western Cengage Learning.

Nitisemito, Alex S. (1992), Manajemen Personalia, Penerbit Ghalia Indonesia. Cetakan ke Delapan, Jakarta.

Putu Agus Erick Sastra Wirawan (2017), Pengaruh Kecerdasan Emosional terhadap Kepuasan dan Kinerja Karyawan PT. Jasa Raharja (persero) Cabang Bali, Jurnal Ekonomi \& Bisnis, Vol. 3, No. 1, Maret 2017, 12-26

Rivai, H. V., dan Sagala, Ella, J (2010). Manajemen Sumber Daya Manusia Untuk Perusahaan, Edisi ke 2, Jakarta: PT. Rajagrafindo.

Robbins, Stephen P. dan Judge, Timothy A (2012). Organizational Behavior 15th ed, New Jersey: Prentice Hall.

Sugiyono. (2012). Metode Penelitian Kuantitatif, Kualitatif, $\quad R \& D . \quad$ Bandung : Alfabeta

Umi Narimawati. 2008. Metodologi Penelitian Kualitatif dan Kuantitatif, Teori dan Aplikasi. Bandung: Agung Media

Wibowo (2014). Manajemen Kinerja, Jakarta: Rajawali Pers.

Wibowo, Ario (2011). Pengaruh Kecerdasan Emosional Terhadap Karyawan Asuransi Perorangan AJB Bumiputera 1912 Malang. Skripsi yang Tidak Dipublikasikan: Universitas Brawijaya Malang. 
130 Coopetition, Vol IX, Nomor 2, November 2018 e-ISSN 2615-4978 